\title{
HUBUNGAN KARAKTERISTIK IBU, FREKUENSI KEHADIRAN ANAK KE POSYANDU, ASUPAN ENERGI DAN PROTEIN DENGAN STATUS GIZI ANAK USIA 1-2 TAHUN
}

\author{
Chairunisa Nur Rarastiti, Ahmad Syauqy ${ }^{*}$ \\ Program Studi Ilmu Gizi Fakultas Kedokteran Universitas Diponegoro \\ Jl.Dr.Sutomo No.18, Semarang, Telp (024) 8453708, Email : gizifk@undip.ac.id
}

\begin{abstract}
Background: Growth development and golden period occurs in early two years of age. Nutritional status is one predictor of life quality in the future. Children nutritional status can be monitoring in posyandu. Posyandu is one from Community Resources of Health Efforts (UKBM) to providing convenience in health services. Children nutritional status also affected by mother's characteristics and nutritional intake. This study aimed to find out the relationship of mother's characteristics, frequency of children attendance in posyandu, energy and protein intake with nutritional status of children aged 1-2 years.

Methods: Analytical study with cross-sectional design. Subjects were 57 mother and children aged 1-2 years who lived in Puskesmas Bugangan's area, Eastern of Semarang. Subject was taken with purposive sampling technique. Mother's characteristic was taken from interview, frequency of children attendance in posyandu was obtained from posyandu register's data, energy and protein intake were taken from food recall and nutritional status was compared with Z-score of WHO 2005. Data was analyzed using rank-spearman and chi square test by computer program.

Results: The result showed 52,6\% children attendance in posyandu. There were $35,1 \%$ and $71,9 \%$ children aged 1 2 years with good energy and protein intake, and also 57,9\% children with good nutrition. There were no relationship of mother's age ( $p=0,909 ; r=-0,015)$, mother's education $(p=0,352 ; R P=1,38)$, mother's occupation ( $p=0,072 ; R P=1,25)$, mother's knowledge ( $p=0,258 ; r=0,152)$, number of child ( $p=0,677 ; r=-0,056)$, family income $(p=0,612 ; r=0,069)$ and frequency of children attendance in posyandu $(p=0,238 ; r=0,159)$ with nutritional status of children aged 1-2 years. There were a relationship between energy $(p=0,000 ; r=0,646)$ and protein intake ( $p=0,000 ; r=0,496)$ with nutritional status of children aged $1-2$ years.

Conclusions: There were no relationship of mother's age, mother's education, mother's occupation, mother's knowledge, number of child, family income and frequency of children attendance in posyandu with nutritional status of children aged 1-2 years. There were a relationship between energy and protein intake with nutritional status of children aged 1-2 years.
\end{abstract}

Keywords: mother's characteristic; frequency of children attendance in posyandu; energy and protein intake; nutritional status; children aged 1-2 years

\begin{abstract}
ABSTRAK
Latar Belakang: Optimalisasi tumbuh kembang dan masa emas pertumbuhan otak terjadi pada dua tahun awal kehidupan. Status gizi merupakan prediktor kualitas hidup di kemudian hari. Status gizi balita dapat dipantau melalui posyandu. Posyandu merupakan Upaya Kesehatan Bersumber Daya Masyarakat (UKBM) untuk memberikan kemudahan dalam memperoleh pelayanan kesehatan dasar. Status gizi anak juga dapat dipengaruhi oleh karakteristik ibu dan asupan makanan. Penelitian ini bertujuan untuk mengetahui hubungan karakteristik ibu, frekuensi kehadiran anak ke posyandu, asupan energi dan protein dengan status gizi anak usia 1-2 tahun.

Metode: Penelitian analitik dengan desain cross sectional. Subjek penelitian 57 ibu dari anak usia 1-2 tahun di wilayah kerja Puskesmas Bugangan Kecamatan Semarang Timur. Teknik pengambilan sampel secara purposive sampling. Karakteristik subjek diperoleh melalui wawancara, frekuensi kehadiran ke posyandu diperoleh dari data register posyandu, asupan energi protein anak dari food recall dan status gizi BB/U anak diperoleh melalui penimbangan kemudian dibandingkan dengan skor Z WHO 2005. Analisis data dengan uji rank-spearman dan chi square menggunakan program komputer.

Hasil: Sebesar 52,6\% frekuensi anak yang aktif hadir ke posyandu. Sebesar 35,1\% dan 71,9\% anak dengan asupan energi dan protein cukup serta 57,9\% dengan status gizi baik. Tidak terdapat hubungan antara usia ibu ( $p=0,909$; $r=-0,015)$, pendidikan ibu $(p=0,352 ; R P=1,38)$, pekerjaan ibu $(p=0,472 ; R P=1,25)$, pengetahuan ibu $(p=0,258$; $r=0,152)$, jumlah balita $(p=0,677 ; r=-0,056)$, pendapatan keluarga $(p=0,612 ; r=0,069)$ dan frekuensi kehadiran ke posyandu $(p=0,238 ; r=0,159)$ dengan status gizi anak usia 1-2 tahun. Ada hubungan antara asupan energi $(p=0,000 ; r=0,646)$ dan protein $(p=0,000 ; r=0,496)$ dengan status gizi anak usia $1-2$ tahun.

Simpulan: Tidak terdapat hubungan bermakna antara usia ibu, pendidikan ibu, pekerjaan ibu, pengetahuan ibu, jumlah balita, pendapatan keluarga dan frekuensi kehadiran anak ke posyandu dengan status gizi anak usia 1-2 tahun. Terdapat hubungan bermakna antara asupan energi dan protein dengan status gizi anak usia 1-2 tahun.
\end{abstract}

${ }^{*}$ Penulis Penanggungjawab 
Kata Kunci: karakteristik ibu; frekuensi kehadiran anak ke posyandu; asupan energi protein; status gizi; anak usia 1-2 tahun

\section{PENDAHULUAN}

Proses optimalisasi tumbuh kembang dan masa emas dalam pertumbuhan otak terjadi pada dua tahun awal kehidupan (window of opportunity). ${ }^{1,2}$ Scaling Up Nutrition (SUN) Movement, merupakan upaya global dari berbagai negara dalam rangka memperkuat komitmen dan rencana aksi percepatan perbaikan gizi. Gerakan tersebut merupakan penanganan gizi selama 1000 hari dari masa kehamilan hingga anak usia dua tahun. ${ }^{1}$

Status gizi merupakan prediktor kualitas sumberdaya manusia. ${ }^{2}$ Penanganan yang tepat pada awal kehidupan anak akan menentukan kualitas hidup mereka di kemudian hari. ${ }^{3}$ Usia dua tahun awal kehidupan rentan dengan berbagai masalah gizi. ${ }^{4}$ Penelitian di India menunjukkan, diabetes dan gangguan toleransi glukosa pada usia dewasa berkaitan dengan berat badan rendah pada usia satu hingga dua tahun kehidupan. ${ }^{5}$ Status gizi dapat dipengaruhi antara lain oleh pola asuh, karakteristik ibu dan asupan makanan (energi dan protein). ${ }^{6}$

Ibu merupakan orang yang paling dekat hubungannya dalam proses tumbuh kembang anak. $^{7}$ Kualitas pengasuhan anak dalam hal kesehatan maupun asupan makan pada anak menjadi hal yang perlu diperhatikan demi mencapai status gizi yang optimal. Penelitian di Kecamatan Gunungpati menyatakan bahwa karakteristik ibu seperti usia, pendidikan, pengetahuan, pekerjaan dan pendapatan merupakan faktor yang ikut menentukan status gizi balita. $^{8}$

Aktif datang ke posyandu untuk menimbang anak balita merupakan upaya untuk memantau kesehatan anak atau meningkatkan status gizinya. Penelitian yang dilakukan di Manyaran Semarang dan Rancaekek, bahwa ibu yang aktif dalam kegiatan posyandu, maka status gizi balitanya baik. ${ }^{9,10}$ Posyandu merupakan Upaya Kesehatan Bersumber Daya Masyarakat (UKBM), yang memberikan kemudahan kepada masyarakat dalam memperoleh pelayanan kesehatan dasar. Posyandu memiliki 5 kegiatan utama yaitu, kegiatan Ibu dan Anak, Keluarga Berencana, imunisasi, gizi, pencegahan dan penanggulangan diare. Sedangkan dalam kegiatan rutin Posyandu terdapat 5 langkah pelayanan, yaitu pendaftaran, penimbangan, pencatatan pada Kartu Menuju Sehat (KMS), penyuluhan dan pelayanan kesehatan. Posyandu diharapkan dapat mempercepat upaya perbaikan status gizi dalam menurunkan angka kematian balita serta prevalensi gizi kurang dan gizi buruk. ${ }^{11,12}$

Keberhasilan posyandu dalam menanggulangi berbagai masalah gizi, dipengaruhi partisipasi masyarakat dalam posyandu. ${ }^{11}$ Tingkat partisipasi masyarakat dalam posyandu suatu wilayah dapat dilihat dari frekuensi kehadiran anak ke posyandu, diukur dengan perbandingan antara jumlah balita di daerah kerja posyandu (S) terhadap jumlah balita yang ditimbang pada setiap kegiatan posyandu (D). Data Dinas Kesehatan Kota Semarang mengenai cakupan D/S pada tahun 2011 menunjukkan angka 77,21\%, dimana angka tersebut masih dibawah target standar pelayanan minimal Provinsi Jawa Tengah yaitu $80 \%{ }^{13}$

Status gizi juga dipengaruhi oleh asupan makanan. Konsumsi energi yang kurang dapat menyebabkan kekurangan gizi dan bila terus berlanjut dapat menyebabkan gizi buruk. Tingkat konsumsi energi yang cukup akan memberi pengaruh terhadap efisiensi penggunaan protein tubuh. Selanjutnya bila terjadi kekurangan protein dalam jangka waktu lama, akan mengakibatkan persediaan protein dalam tubuh semakin berkurang sehingga mengakibatkan Kwashiorkor. ${ }^{14}$ Menurut data Dinas Kesehatan Kota Semarang tahun 2011, prevalensi gizi kurang pada balita sebesar 0,98\% dan gizi buruk sebesar $0,06 \%{ }^{15}$

Hasil survei Dinas Kesehatan Kota Semarang menunjukkan Puskesmas Bugangan termasuk puskesmas dengan cakupan D/S yang rendah di Kota Semarang tahun 2011, yaitu $73,90 \% .^{13}$ Berdasarkan uraian masalah tersebut, peneliti tertarik melakukan penelitian yang bertujuan untuk mengetahui hubungan karakteristik ibu, frekuensi kehadiran anak ke posyandu, serta asupan energi dan protein dengan status gizi anak usia 1-2 tahun di wilayah kerja Puskesmas Bugangan Kecamatan Semarang Timur Kota Semarang.

\section{METODE PENELITIAN}

Penelitian ini termasuk lingkup gizi masyarakat, dilaksanakan Juli-Agustus 2013. Jenis penelitian adalah penelitian analitik dengan desain cross-sectional. Penelitian dilakukan pada ibu yang memiliki anak usia 1-2 tahun di wilayah kerja Puskesmas Bugangan Kecamatan Semarang Timur. Jumlah subjek sebanyak $57 \mathrm{ibu}$ yang 
diperoleh secara purposive sampling. Kriteria inklusi dalam penelitian ini adalah anak usia 1-2 tahun dan anak tidak sedang dalam keadaan sakit atau mengalami penyakit infeksi selama dilaksanakan penelitian. Kriteria eksklusi dalam penelitian ini adalah subjek tidak lagi menjadi anggota di wilayah kerja posyandu dan mengundurkan diri sebagai subjek penelitian.

Variabel independen dalam penelitian ini adalah karakteristik ibu meliputi usia, pendidikan, pengetahuan, pekerjaan, jumlah balita dan pendapatan keluarga, frekuensi kehadiran anak ke posyandu, serta asupan energi dan protein anak usia 1-2 tahun. Variabel dependen dalam penelitian ini adalah status gizi anak usia 1-2 tahun. Tahap pengambilan data yaitu melihat data register atau buku penimbangan di posyandu untuk memperoleh data partisipasi/ kunjungan anak usia 1-2 tahun ke posyandu. Kemudian dilakukan kunjungan rumah untuk wawancara mengenai identitas ibu dan anak, kuesioner penelitian, asupan makan anak usia 1-2 tahun serta pengukuran berat badan anak usia 1-2 tahun.

Usia ibu didapatkan dari selisih antara tahun penelitian dengan tahun kelahiran ibu dan hasil dinyatakan dalam tahun. Dikategorikan dewasa muda 15-31 tahun dan dewasa tua 32-49 tahun. ${ }^{16}$ Pendidikan ibu adalah pendidikan formal yang pernah dijalani ibu, diperoleh dari ijazah terakhir, dikategorikan pendidikan tinggi (tamat SMA dan diploma/perguruan tinggi) dan pendidikan rendah (tidak sekolah, tamat SD dan tamat SMP). Pengetahuan ibu adalah tingkat pemahaman ibu tentang gizi yang diukur menggunakan kuesioner dengan ketentuan nilai 0 jika jawaban salah dan 1 bila benar, kemudian dilakukan penjumlahan skor dibagi jumlah pertanyaan dikali $100 \%$. Dikategorikan berpengetahuan baik jika jawaban benar $>80 \%$ dan berpengetahuan kurang bila jawaban benar $\leq 80 \% .{ }^{17}$ Pekerjaan ibu adalah status pekerjaan ibu dalam kesehariannya. Jumlah balita dalam keluarga adalah banyaknya balita yang ditanggung dalam satu keluarga. Pendapatan keluarga adalah pendapatan keluarga tiap bulan, untuk memenuhi kebutuhan sehari-hari, baik pangan maupun non pangan. Dikategorikan tinggi $>$ Rp 1.209.100,00 dan rendah $\leq \mathrm{Rp} 1.209 .100,00{ }^{18}$

Frekuensi kehadiran anak ke posyandu untuk ditimbang diperoleh melalui data kader posyandu pada masing-masing posyandu di wilayah kerja Puskesmas Bugangan pada bulan Juli 2012 - Juni 2013. Dikategorikan aktif bila frekuensi kunjungan ke posyandu $\geq 8 \mathrm{kali} / \mathrm{tahun}$ dan tidak aktif bila $<8 \mathrm{kali} / \mathrm{tahun} .{ }^{19}$ Asupan energi dan protein anak usia 1-2 tahun bersumber dari makanan yang dikonsumsi sehari-hari. Pencatatan asupan makan dilakukan selama 3 hari tidak berturut-turut menggunakan formulir recall 24 jam dalam ukuran rumah tangga (URT) dan dihitung menggunakan nutrisoft. Rata-rata asupan energi dan protein dihitung berdasarkan total asupan dalam 3 hari dibagi 3. Asupan energi dan protein yang didapat dibandingkan dengan Angka Kecukupan Gizi (AKG) kemudian dikalikan 100\%. Dikategorikan menjadi cukup ( $\geq 100 \%)$ dan kurang $(<100 \%) .^{14}$

Status gizi anak usia 1-2 tahun adalah keseimbangan antara zat gizi yang masuk ke dalam tubuh dengan kebutuhan gizi yang diperlukan tubuh dan dianalisis berdasarkan indeks berat badan menurut umur $(\mathrm{BB} / \mathrm{U})$ menurut baku standar antropometri WHO 2005. Indikator ini dilihat melalui pengukuran z-score dan dikategorikan menjadi gizi baik $(\geq-2$ SD) dan gizi kurang $(<-2$ SD). ${ }^{20}$ Berat badan anak usia 1-2 tahun didapatkan dari pengukuran langsung satu kali saat melakukan penelitian menggunakan timbangan injak digital dengan kapasitas $200 \mathrm{~kg}$ dan tingkat ketelitian 0,1 $\mathrm{kg}$ dengan baju minimal (tanpa sepatu, topi, dll).

Pengolahan dan analisis data dilakukan dengan program komputer. Analisis univariat dilakukan untuk mengidentifikasi karakteristik dan variabel penelitian. Analisis bivariat dilakukan uji korelasi Rank Spearman untuk mengetahui hubungan usia ibu, pengetahuan ibu, jumlah balita dalam keluarga, pendapatan keluarga, frekuensi kehadiran anak ke posyandu, serta asupan energi dan protein dengan status gizi anak usia 1-2 tahun. Sedangkan uji Chi Square untuk mengetahui hubungan pendidikan dan pekerjaan ibu dengan status gizi anak usia 1-2 tahun.

\section{HASIL PENELITIAN \\ Analisis Univariat}

Jumlah subjek dalam penelitian ini sebanyak 57 subjek. Frekuensi kehadiran anak yang aktif ke posyandu sebanyak 52,6\%. Anak usia 1-2 tahun dengan asupan energi dan protein cukup berturut-turut sebanyak 20 anak $(35,1 \%)$ dan 41 anak $(71,9 \%)$ dengan rerata asupan energi dan protein berturut-turut sebesar $862,39 \pm 256,72$ SD dan $31,81 \pm 11,15$ SD. Status gizi anak usia 1-2 tahun berdasarkan BB/U untuk kategori gizi baik sebanyak 33 anak $(57,9 \%)$ dan gizi kurang sebanyak 24 anak $(42,1 \%)$, dengan $z$-score antara $2,98-1,11$. 
Tabel 1. Distribusi Frekuensi Karakteristik Ibu, Frekuensi Kehadiran Anak ke Posyandu, Asupan Energi dan Protein anak usia 1-2 tahun, Status Gizi anak usia 1-2 tahun

\begin{tabular}{|c|c|c|}
\hline Karakteristik Ibu & $\mathbf{n}$ & $\%$ \\
\hline \multicolumn{3}{|l|}{ Usia Ibu } \\
\hline - Dewasa Tua (32 - 49 Tahun) & 25 & $43,9 \%$ \\
\hline - Dewasa Muda (15 - 31 Tahun) & 32 & $56,1 \%$ \\
\hline \multicolumn{3}{|l|}{ Pendidikan Ibu } \\
\hline - Rendah & 11 & $19,3 \%$ \\
\hline - Tinggi & 46 & $80,7 \%$ \\
\hline \multicolumn{3}{|l|}{ Pengetahuan Ibu } \\
\hline - Kurang $(\leq 80 \%$ jawaban benar $)$ & 31 & $54,4 \%$ \\
\hline - $\quad$ Baik $(>80 \%$ jawaban benar $)$ & 26 & $45,6 \%$ \\
\hline \multicolumn{3}{|l|}{ Pekerjaan Ibu } \\
\hline - Bekerja & 23 & $40,4 \%$ \\
\hline _ Tidak bekerja & 34 & $59,6 \%$ \\
\hline \multicolumn{3}{|l|}{ Jumlah balita dalam keluarga } \\
\hline$-\quad>1$ balita & 21 & $32,8 \%$ \\
\hline - 1 balita & 36 & $63,2 \%$ \\
\hline \multicolumn{3}{|l|}{ Pendapatan Keluarga } \\
\hline - $\quad$ Rendah $(\leq \operatorname{Rp} 1.209 .100,00)$ & 19 & $33,3 \%$ \\
\hline$-\quad$ Tinggi (>Rp 1.209.100,00) & 38 & $66,7 \%$ \\
\hline \multicolumn{3}{|c|}{ Frekuensi Kehadiran Anak ke Posyandu } \\
\hline Tidak aktif (<8 kali/tahun) & 27 & $47,4 \%$ \\
\hline Aktif ( $\geq 8 \mathrm{kali} /$ tahun $)$ & 30 & $52,6 \%$ \\
\hline \multicolumn{3}{|c|}{$\begin{array}{l}\text { Asupan Zat Gizi Anak Usia 1-2 Tahun } \\
\end{array}$} \\
\hline \multicolumn{3}{|c|}{ e } \\
\hline - Kurang $(<100 \%)$ & 37 & $64,9 \%$ \\
\hline$-\quad$ Cukup $(>100 \%)$ & 20 & $35,1 \%$ \\
\hline \multicolumn{3}{|l|}{ Protein } \\
\hline - $\quad$ Kurang $(<100 \%)$ & 16 & $28,1 \%$ \\
\hline - $\quad$ Cukup $(\geq 100 \%)$ & 41 & $71,9 \%$ \\
\hline \multicolumn{3}{|c|}{ Status Gizi Anak Usia 1-2 Tahun } \\
\hline $\mathrm{BB} / \mathrm{U}$ & & \\
\hline - $\quad$ Gizi kurang $(<-2 S D$ s.d $-3 \mathrm{SD})$ & 24 & $42,1 \%$ \\
\hline - $\quad$ Gizi baik $(\geq-2 S D$ s.d $+2 S D)$ & 33 & $57,9 \%$ \\
\hline
\end{tabular}

\section{Analisis Bivariat}

Analisis Bivariat menggunakan uji korelasi Rank Spearman menunjukkan tidak ada hubungan antara usia ibu $(p=0,909 ; \mathrm{r}=-0,015)$, pengetahuan ibu $(p=0,258 ; \mathrm{r}=0,152)$, jumlah balita $(p=0,677 ; \mathrm{r}=-$ $0,056)$, pendapatan keluarga $(p=0,612 ; \mathrm{r}=0,069)$ dan frekuensi kehadiran anak ke posyandu $(p=0,238 ; \mathrm{r}=0,159)$ dengan status gizi anak usia 12 tahun. Ada hubungan antara asupan energi $(p=0,000 ; \mathrm{r}=0,646)$ dan protein $(p=0,000 ; \mathrm{r}=0,496)$ dengan status gizi anak usia 1-2 tahun.

Tabel 2. Korelasi Usia Ibu, Pengetahuan Ibu, Jumlah balita, Pendapatan keluarga, Frekuensi Kehadiran Anak ke Posyandu, Asupan Energi dan Protein dengan Status Gizi Anak usia 1-2 tahun

\begin{tabular}{lccc}
\hline & \multicolumn{3}{c}{ Status Gizi } \\
\cline { 2 - 4 } & $\mathbf{n}$ & $\boldsymbol{p}$ & $\mathbf{r}$ \\
\hline Usia Ibu & 57 & 0,909 & $-0,015$ \\
\hline Pengetahuan Ibu & 57 & 0,258 & 0,152 \\
\hline Jumlah balita dalam keluarga & 57 & 0,677 & $-0,056$ \\
\hline Pendapatan keluarga & 57 & 0,612 & 0,069 \\
\hline Frekuensi kehadiran anak ke posyandu & 57 & 0,238 & 0,159 \\
\hline Asupan energi anak usia 1-2 tahun & 57 & 0,000 & 0,646 \\
\hline Asupan protein anak usia 1-2 tahun & 57 & 0,000 & 0,496 \\
\hline
\end{tabular}

*Uji Rank-Spearman 
Analisis Bivariat menggunakan uji Chi Square menunjukkan tidak ada hubungan antara pendidikan ibu $(p=0,352 ; \mathrm{RP}=1,38)$ dan pekerjaan ibu ( $p=0,472 ; \mathrm{RP}=1,25)$ dengan status gizi anak usia 1-2 tahun.

Tabel 3. Tabel Silang Pendidikan dan Pekerjaan Ibu dengan Status Gizi Anak usia 1-2 tahun

\begin{tabular}{lccccc}
\hline & $\begin{array}{c}\text { Gizi Kurang } \\
\mathbf{n = 2 4}(\%)\end{array}$ & $\begin{array}{c}\text { Gizi Baik } \\
\mathbf{n = 3 3}(\%)\end{array}$ & $\begin{array}{c}\text { Total } \\
\mathbf{n = 5 7}(\%)\end{array}$ & $\boldsymbol{p}$ & $\mathbf{R P}$ \\
\hline $\begin{array}{l}\text { Karakteristik Ibu } \\
\text { Pendidikan Ibu }\end{array}$ & & & & & \\
$-\quad$ Rendah & $6(54,5 \%)$ & $5(45,5 \%)$ & $11(100 \%)$ & 0,352 & 1,38 \\
$\quad$ Tinggi & $18(39,1 \%)$ & $28(60,9 \%)$ & $46(100 \%)$ & & \\
Pekerjaan Ibu & $11(47,8 \%)$ & $12(52,2 \%)$ & $23(100 \%)$ & 0,472 & 1,25 \\
$-\quad$ Bekerja & $13(38,3 \%)$ & $21(61,7 \%)$ & $34(100 \%)$ & & \\
$-\quad$ Tidak bekerja & & & & \\
\hline
\end{tabular}

\section{PEMBAHASAN}

Frekuensi kehadiran anak ke posyandu menunjukkan prevalensi sebesar 52,6\%. Prevalensi tersebut rendah karena tidak mencapai target SPM Jawa Tengah yaitu $80 \% .{ }^{17}$ Kegiatan posyandu di wilayah kerja Puskesmas Bugangan dilaksanakan pada pagi hari. Faktor ibu yang bekerja $(40,4 \%)$, baik ibu yang aktif maupun tidak aktif atau adanya kesibukan dapat menyebabkan ibu berhalangan hadir ke posyandu. Anak dengan asupan energi cukup sebesar $35,1 \%$ dan asupan protein cukup sebesar 75,9\%. Sejalan dengan Riskesdas tahun 2007 dan 2010, yang menyatakan bahwa $<70 \%$ anak balita di Indonesia dengan asupan energi dan $<80 \%$ dengan asupan protein yang belum memenuhi AKG. ${ }^{6,21}$ Anak usia 1-2 tahun dengan status gizi kurang di wilayah kerja Puskesmas Bugangan, sebesar 42,1\%. Dibandingkan dengan Riskesdas 2010 yang menunjukkan prevalensi gizi kurang sebesar $13 \%^{21}$, maka anak usia 1-2 tahun dengan status gizi kurang di wilayah kerja Puskesmas Bugangan tergolong tinggi (buruk).

Hasil analisis dalam penelitian ini menunjukkan tidak ada hubungan antara usia ibu dengan status gizi anak usia 1-2 tahun. Hasil tersebut sejalan dengan penelitian lain di Gunungpati Semarang, yang menyatakan bahwa tidak ada hubungan antara usia ibu dengan status gizi anak. ${ }^{8}$ Usia sebagai salah satu faktor yang mempengaruhi partisipasi sosial. Ibu dengan usia dewasa muda lebih mudah menerima instruksi sedangkan ibu dengan usia dewasa tua lebih berpengalaman dalam pola pengasuhan balitanya. ${ }^{16}$ Tidak ada hubungan antara usia ibu dengan status gizi anak usia 1-2 tahun dalam penelitian ini kemungkinan karena masing-masing ibu dalam mengasuh anaknya memiliki cara yang berbedabeda, sehingga ibu yang berusia dewasa muda maupun dewasa tua dapat memiliki anak dengan status gizi yang baik atau kurang.

Hasil analisis dalam penelitian ini menunjukkan tidak ada hubungan antara pendidikan dan pengetahuan ibu dengan status gizi anak usia 1-2 tahun. Hasil tersebut sejalan dengan penelitian lain di Sidoarjo yang menyatakan bahwa pendidikan yang tinggi belum tentu menjamin bahwa ibu mengerti tentang hal-hal yang mempengaruhi status gizi anak ${ }^{22}$, serta penelitian di Padang yang menyatakan bahwa tidak ada hubungan antara pengetahuan ibu dengan status gizi anak. ${ }^{23}$ Ibu dengan pendidikan yang tinggi lebih mudah untuk menerima informasi tentang cara pengasuhan anak yang baik dan menjaga kesehatan. Namun, ilmu pengetahuan juga selalu berkembang dan di era yang semakin maju, pengetahuan dapat diperoleh dari berbagai media. Maka, ibu dengan latar pendidikan yang rendah namun rajin mendengar atau melihat informasi mengenai gizi juga dapat memberikan asupan makanan kepada balitanya dengan tepat. ${ }^{7,16}$ Tidak adanya hubungan antara pendidikan dan pengetahuan ibu dengan status gizi anak usia 1-2 tahun dalam penelitian ini dapat disebabkan karena dengan semakin mudahnya akses pengetahuan atau informasi mengenai kesehatan dari berbagai media maka ibu dengan latar belakang pendidikan tinggi maupun rendah akan dapat memberikan pengasuhan yang baik dan tepat untuk anaknya, sehingga status gizinya akan baik.

Hasil analisis dalam penelitian ini menunjukkan tidak ada hubungan antara pekerjaan ibu dan pendapatan keluarga dengan status gizi anak usia 1-2 tahun. Hasil tersebut sejalan dengan penelitian lain di Ungaran Kabupaten Semarang, yang menyatakan bahwa pekerjaan ibu tidak mempengaruhi status gizi anak ${ }^{24}$ dan penelitian di 
Modayag Barat Manado, yang menyatakan bahwa pendapatan orangtua tidak mempengaruhi asupan dan status gizi anak. ${ }^{25}$ Pada umumnya, ibu yang tidak bekerja akan mempunyai waktu lebih untuk memberikan perhatian kepada anaknya, dibandingkan ibu yang bekerja. ${ }^{16}$ Tidak adanya hubungan antara pekerjaan ibu dengan status gizi anak usia 1-2 tahun dalam penelitian ini dapat disebabkan karena ibu yang bekerja juga bisa secara bersama atau dibantu oleh anggota keluarga lain untuk ikut mengasuh anaknya sehingga status gizinya dapat tetap terpantau.

Ibu yang bekerja dapat menambah pendapatan keluarga. Tingkat pendapatan menentukan makanan yang dibeli, dimana semakin tinggi pendapatan keluarga maka gizi anak juga akan tercukupi dan berpengaruh terhadap status gizinya. ${ }^{16}$ Keluarga dengan pendapatan yang tinggi belum tentu memperbaiki komposisi makanan sehingga belum tentu mutu makanannya lebih baik. ${ }^{26}$ Tidak adanya hubungan antara pendapatan keluarga dengan status gizi anak usia 1-2 tahun dalam penelitian ini dapat disebabkan karena tidak diketahui seberapa besar pendapatan yang digunakan untuk membeli makanan.

Jumlah anak balita dalam keluarga merupakan salah satu faktor yang mempengaruhi pola asuh ibu. Jika jarak usia anak terlalu dekat, maka perhatian ibu akan berkurang. ${ }^{16}$ Hasil analisis dalam penelitian ini menunjukkan tidak ada hubungan antara jumlah balita dalam keluarga dengan status gizi anak usia 1-2 tahun. Sejalan dengan penelitian lain di Sidoarjo, yang menyatakan bahwa banyaknya anak dalam keluarga tidak berpengaruh terhadap status gizi balita. ${ }^{22}$ Tidak adanya hubungan antara jumlah balita dalam keluarga dengan status gizi anak usia 1-2 tahun dalam penelitian ini dapat disebabkan karena ibu dalam mengasuh balitanya dapat dibantu oleh anggota keluarga lain atau oleh jasa pengasuh. Sehingga ibu yang memiliki balita lebih dari satu juga dapat terus memantau asupan maupun aktivitas anaknya sehingga status gizinya pun akan baik.

Hasil analisis dalam penelitian ini menunjukkan tidak terdapat hubungan antara frekuensi kehadiran anak ke posyandu dengan status gizi anak usia 1-2 tahun. Hasil tersebut sejalan dengan penelitian di Purworejo dan Bone, yang menyatakan tidak ada hubungan antara tingkat partisipasi ibu dalam kegiatan posyandu dengan status gizi anak bawah dua tahun. ${ }^{27,28}$ Partisipasi masyarakat untuk datang dan menimbang anak balitanya di posyandu dimaksudkan agar status gizi balita dapat terus dipantau. Dalam kegiatan rutin posyandu, juga terdapat pelayanan penyuluhan. Penyuluhan bermanfaat bagi masyarakat atau ibu untuk menambah pengetahuan tentang kesehatan dan gizi, sehingga apabila diaplikasikan dalam kehidupan sehari-hari maka akan terwujud pola hidup sehat bagi keluarganya. ${ }^{11}$ Berdasarkan fakta di posyandu wilayah kerja Puskesmas Bugangan, masyarakat memang datang untuk menimbang anak balitanya, namun penyuluhan belum rutin diberikan pada setiap kegiatan rutin posyandu. Sebenarnya diharapkan penyuluhan rutin diberikan agar selain kegiatan penimbangan, masyarakat juga dapat memperoleh manfaat lain dari penyuluhan. Tidak adanya hubungan antara frekuensi kehadiran anak ke posyandu dengan status gizi anak usia 1-2 tahun dalam penelitian ini dapat disebabkan karena masyarakat yang datang ke posyandu memang datang untuk menimbang anak balitanya, namun manfaat dari penyuluhan belum maksimal, sehingga tidak berpengaruh terhadap status gizi anak.

Ada hubungan dan korelasi positif yang kuat antara asupan energi $(p=0,000 ; \mathrm{r}=0,646)$ dan protein $(p=0,000 ; \mathrm{r}=0,496)$ dengan status gizi anak usia 1-2 tahun, yang berarti bahwa semakin tinggi asupan energi dan protein maka status gizi anak akan semakin baik. Energi merupakan zat yang digunakan untuk metabolisme basal, aktivitas, pertumbuhan maupun pembuangan sisa makanan (eliminasi). ${ }^{29}$ Protein merupakan zat pembangun yang dibutuhkan untuk pertumbuhan, mengganti sel-sel yang rusak dan memelihara keseimbangan metabolisme tubuh. Kebutuhan protein bagi balita relatif lebih besar dari orang dewasa, karena balita mengalami pertumbuhan dan perkembangan yang pesat. ${ }^{25}$ Penelitian lain yang dilakukan di Tasikmalaya dan Blora, menyatakan bahwa konsumsi makanan berpengaruh terhadap status gizi seseorang. Konsumsi energi dan protein yang kurang selama jangka waktu tertentu akan menyebabkan kurang gizi. Tingkat konsumsi ditentukan oleh kualitas serta kuantitas hidangan. Status gizi baik dapat dicapai bila tubuh memperoleh cukup zat-zat yang akan digunakan, sehingga pertumbuhan fisik dan perkembangan otak dapat bekerja optimal. ${ }^{30,31}$ Sedangkan penelitian yang dilakukan di Semarang Utara dan Tallo Makassar, menyatakan bahwa anak dengan asupan makanan yang cukup maupun kurang dapat memiliki status gizi kurang. Hal tersebut dapat disebabkan karena penyakit. Anak dengan asupan makanan cukup tetapi sering diare atau demam 
maka dapat menderita kurang gizi, begitu juga dengan anak dengan asupan makanan kurang maka daya tahan tubuh makin melemah sehingga mudah terserang penyakit dan dapat menderita kurang gizi. $^{32,33}$

\section{SIMPULAN}

Sebanyak 52,6\% frekuensi anak yang aktif ditimbang di posyandu. Sebanyak $35,1 \%$ anak usia 1-2 tahun dengan asupan energi cukup, 75,9\% dengan asupan protein cukup dan $57,9 \%$ dengan status gizi baik. Tidak terdapat hubungan bermakna antara usia ibu, pendidikan ibu, pengetahuan ibu, pekerjaan ibu, jumlah balita dalam keluarga, pendapatan keluarga dan frekuensi kehadiran anak ke posyandu dengan status gizi anak usia 1-2 tahun. Terdapat hubungan bermakna dan korelasi yang kuat antara asupan energi dan asupan protein dengan status gizi anak usia 1-2 tahun, menunjukkan bahwa asupan energi dan asupan protein dapat mempengaruhi status gizi.

\section{SARAN}

Posyandu memberikan kemudahan kepada masyarakat dalam memperoleh pelayanan kesehatan dasar. Posyandu memiliki fungsi preventif dan salah satu pelayanan posyandu terdapat penyuluhan yang apabila diimplementasikan dalam kehidupan masyarakat sehari-hari diharapkan akan dapat memberikan manfaat terhadap kesehatan. Perlu diberikan pelatihan dan ketrampilan untuk kader dalam hal penyuluhan, sehingga pengetahuan kader semakin luas dan nantinya akan disalurkan kepada masyarakat dalam setiap kegiatan rutin posyandu. Penyuluhan diberikan secara rutin agar masyarakat dapat memperoleh manfaat dari penyuluhan tersebut dan minat masyarakat untuk datang ke posyandu semakin meningkat. Pengetahuan gizi melalui penyuluhan diberikan kepada masyarakat maupun ibu, agar dapat menerapkan pola hidup sehat dan agar lebih memperhatikan asupan gizi untuk keluarganya, sehingga akan tercapai status gizi yang baik bagi keluarga khususnya bagi anak.

\section{DAFTAR PUSTAKA}

1. Republik Indonesia. Gerakan Sadar Gizi dalam Rangka Seribu Hari Pertama Kehidupan (1000 HPK). Kerangka Kebijakan 2012. Jakarta; 2012.p.7

2. Irwin LG, Siddiqi A, Hertzman C. Early Child Development: A Powerful Equalizer. World Health Organization; 2007.

3. Badan Perencanaan Pembangunan Nasional (Bappenas). Rencana Aksi Nasional Pangan dan
Gizi 2011-2015. Jakarta: Kementerian Perencanaan Pembangunan Nasional, 2011.p.26, 33

4. Unicef Indonesia. Maternal and Child Nutrition. Issue Briefs, October 2012.

5. Victora CG, Adair L, Fall C, Hallal PC, Martorell R, Richter L, et al., for the Maternal and Child Undernutrition Study Group. Maternal and child undernutrition: consequences for adult health and human capital. Lancet [serial online]. 2008; 371: 340-357.

6. Badan Penelitian dan Pengembangan Kesehatan Kementerian Kesehatan RI. Riset Kesehatan Dasar (RISKESDAS). Laporan Hasil Riset Kesehatan Dasar 2007. Jakarta; 2007.

7. Santoso S, Ranti LA. Kesehatan dan Gizi. Jakarta: PT.Rineka Cipta; 2005.

8. Himawan AW. Hubungan antara Karakteristik Ibu dengan Status Gizi Balita di Kelurahan Sekaran Kecamatan Gunung Pati Semarang [skripsi]. Universitas Negeri Semarang. 2006.

9. Yogiswara BA. Hubungan Tingkat Partisipasi Ibu di Posyandu dengan Status Gizi Balita [skripsi]. Universitas Diponegoro. 2011.

10. Ulfa O, Neti J, Ai M. Hubungan Keaktifan Keluarga Dalam Kegiatan Posyandu dengan Status Gizi Balita di Desa Rancaekek Kulon Kecamatan Rancaekek [skripsi]. Universitas Padjadjaran. 2008.

11. Sulistyorini CI, Pebriyanti S, Proverawati A. Posyandu dan Desa Siaga; Panduan untuk Bidan dan Kader. Yogyakarta: Nuha Medika; 2010.p.3,4,13,20,21,30.

12. Bappenas (National Development Planning Agency) \& Ministry of Health (2010). The Landscape Analysis: Indonesia Country Assessment. Final Report, 6 September 2010.

13. Dinas Kesehatan Kota Semarang. Rekap SKDN Kota Semarang Tahun 2011. Semarang. 2011.

14. Supariasa IDN, Bakri B, Fajar I. Penilaian Status Gizi. edisi 1. Jakarta: Penerbit Buku Kedokteran EGC; 2002.p.94,114.

15. Dinas Kesehatan Kota Semarang. Profil Kesehatan Kota Semarang 2011. Semarang: Dinkes Semarang, 2011.

16. Notoatmodjo S. Pendidikan dan Ilmu Perilaku Kesehatan. edisi 1. Jakarta: Rineka Cipta; 2003.p.114.

17. Khomsan A. Teknik Pengukuran Pengetahuan Gizi. Bogor: IPB. 2004

18. Badan Pusat Statistik. UMR Kota Semarang 2012. Semarang. 2012.

19. Biro Hukum dan Organisasi Sekretaris Jenderal Departemen kesehatan Republik Indonesia. Keputusan Menteri Kesehatan RI Nomor: 828/MENKES/SK/IX/2008; tentang Petunjuk Teknis Standar Pelayanan Minimal Bidang Kesehatan di Kabupaten/Kota. Jakarta: Depkes RI, 2008. 
20. Kementerian Kesehatan RI. Standar Antropometri Penilaian Status Gizi Anak. Jakarta: Direktorat Jenderal Bina Gizi dan Kesehatan Ibu dan Anak; 2010.

21. Badan Penelitian dan Pengembangan Kesehatan Kementerian Kesehatan RI. Riset Kesehatan Dasar (RISKESDAS). Laporan Hasil Riset Kesehatan Dasar 2010. Jakarta; 2010.

22. Agustina L, Luciana, Qomariah Y, Khotimah, H. Gambaran Faktor yang Berhubungan dengan Angka Keberhasilan Penimbangan di Desa Sawotratap Gedangan Kabupaten Sidoarjo [skripsi]. Universitas Wijaya Kusuma Surabaya. 2008.

23. Merdawati L, Putri DE. Perilaku Ibu terhadap Kartu Menuju Sehat (KMS) Balita dan Hubungannya dengan Status Gizi Balita di Kecamatan Padang Timur Padang [skripsi]. 2008.

24. Retnaningsih Ch, Putra BS, Sumardi. Penilaian Status Gizi Berdasarkan Kecukupan Energi dan Protein Balita Usia 3-5 Tahun di Desa Gogik Kecamatan Ungaran Barat Kabupaten Semarang [skripsi]. Unika Soegijapranata. 2011.

25. Djola R. Hubungan antara Tingkat Pendapatan Keluarga dan Pola Asuh dengan Status Gizi Anak Balita di Desa Bongkudai Kecamatan Modayag Barat [skripsi]. Universitas Sam Ratulangi; 2011.

26. Gunawan G, Fadlyana E, Rusmil K. Hubungan Status Gizi dan Perkembangan Anak Usia 1-2 Tahun. Sari Pediatri 2011; 13(2): 142-6.

27. Nurhayati I, Hakimi M, Hartini N. Hubungan Kesejahteraan Gizi Keluarga dengan Status Gizi Anak Bawah Dua Tahun (Baduta) di Kabupaten Purworejo [skripsi]. Politeknik Kesehatan Depkes RI, Medan. 2004.

28. Pakhri A, Fanny L, Faridah St. Pendidikan Ibu, Keteraturan Penimbangan, Asupan Gizi dan Status Gizi Anak Usia 0-24 bulan [skripsi]. Politeknik Kesehatan Kemenkes, Makassar. 2011.

29. Arisman MB. Gizi dalam Daur Kehidupan Jakarta: EGC; 2004.

30. Fatimah S, Nurhidayah I, Rakhmawati W. Faktorfaktor yang Berkontribusi Terhadap Status Gizi Balita di Kecamatan Ciawi Kabupaten Tasikmalaya [skripsi]. Universitas Padjajaran. 2008.

31. Sulistyowati H. Hubungan antara Pengetahuan Ibu dan Pola Pemberian Makanan Pendamping ASI dengan Status Gizi Balita Usia 4-24 Bulan di Desa Sendangharjo Kecamatan Blora Kabupaten Blora [skripsi]. Universitas Negeri Semarang. 2007.

32. Faradevi R. Perbedaan Besar Pengeluaran Keluarga, Jumlah Anak Serta Asupan Energi dan Protein Balita antara Balita Kurus dan Balita Normal [skripsi]. Universitas Diponegoro; 2011.

33. Sakti RE, Hadju V, Rochimiwati SN. Hubungan Pola Pemberian MP-ASI dengan Status Gizi Anak Usia 6-23 Bulan di Wilayah Pesisir Kecamatan
Tallo Kota Makassar [skripsi]. Universitas Hasanuddin Makassar; 2013. 